\title{
A Framework to Identify Economic and Community Benefits of the Proposed BRT System in Southeast Michigan
}

\author{
Utpal Dutta \\ Civil, Architectural, Environmental Engineering, University of Detroit Mercy, Detroit, MI, USA \\ Email: duttau@udmercy.edu
}

How to cite this paper: Dutta, U. (2017) A Framework to Identify Economic and Community Benefits of the Proposed BRT System in Southeast Michigan. Current Urban Studies, 5, 164-184.

https://doi.org/10.4236/cus.2017.52010

Received: March 7, 2017

Accepted: June 9, 2017

Published: June 12, 2017

Copyright ( 2017 by author and Scientific Research Publishing Inc. This work is licensed under the Creative Commons Attribution International License (CC BY 4.0).

http://creativecommons.org/licenses/by/4.0/

\begin{abstract}
In recent years, Bus Rapid Transit (BRT) has generated great interest across the United States. There are more than 20 BRT systems in existence and more are in the planning stage (including Detroit). Within the next few years, BRT will be planned and implemented phase by phase in various parts of Southeast Michigan. The purpose of this paper is to present a framework to identify probable economic and community benefits (quantitative as well as qualitative) of BRT in Southeast Michigan. Taxable Real Estate property, employment sector, population age group, daily vehicle miles traveled, as well as congestion level data were reviewed to identify Southeast Michigan's current and future trends. A Shift-Share analysis using data from Cleveland was performed to determine BRT-advantaged age group. The authors suggested a number of action items to attract choice riders and excite transit dependent riders to the planned BRT system. Based on the literature review and analysis, the authors identified BRT-advantaged job sectors and age-groups within the Southeast Michigan region. As BRT will be implemented in phases, it will affect the amount, type and time of investment. Considering this uncertainty in implementation, projected economic benefit as a function of type and amount of investment was presented. It is to be noted that in order to achieve the desired outcome the system must be planned/designed/implemented within the context of Southeast Michigan rather than just copying a successful system from somewhere else.
\end{abstract}

\section{Keywords}

Bus Rapid Transit, Economic Impact, Community Benefit, Attributes, South East Michigan

\section{Introduction}

Bus Rapid Transit (BRT) has generated great interest among small and large ci- 
ties across the United States (Detroit, MI, Grand Rapids, MI, and Aspen, CO, for example) as a means of improving mobility and accessibility, and optimizing use of street space, at a relatively modest cost per mile ( $\$ 10$ - \$27 million) (Kittelson \& Associates, 2007). The main advantage of BRT is its ability to operate on all types of road infrastructures: mixed-flow arterials, mixed-flow freeways, dedicated arterial lanes, at-grade or full-grade-separated transit ways, managed lanes, and tunnels. Southeast Michigan officials have selected BRT as their preferred choice of future public transit. Within the next few years (most likely starting in 2016), BRT will be planned and implemented phase by phase in the Southeast Michigan counties of Wayne, Oakland, Macomb, and Washtenaw. This effort aims to synthesize available evidence regarding BRT (also other transit system) performance, cost and impact to identify the potential economic impacts of BRT for Southeast Michigan and to determine which among the various component elements and features available for BRT systems would potentially provide the greatest benefits, given the region's unique characteristics.

\subsection{What Is BRT?}

BRT has been defined by the Federal Transit Administration (FTA) as a rapid mode of transportation that can provide the quality of rail transit and the flexibility of buses (Kittelson \& Associates, 2007). Transit Cooperative Research Program (TCRP) Report 90 expanded this definition to "a rubber-tired form of rapid transit that can combine stations, vehicles, services, runways, and ITS (Intelligent Transportation System) elements into an integrated system with a strong image and identity" (Kittelson \& Associates, 2007). In other words, BRT is an integrated system of facilities, equipment, services, and amenities that improves the speed, reliability (level of service), and identity of bus transit. In many respects, BRT is a hybrid, rubber-tired light rail transit (LRT) with greater operating flexibility and relatively lower implementation cost. While BRT provides substantial opportunity to address mobility problems at a lower cost, the size and population density of many US cities have posed unique challenges for BRT implementation, such as short-term inconvenience during construction. Especially, in older cities, such as Detroit and its metropolitan region, issues such as traffic impacts, physical separation, and underground infrastructure (utilities, power lines, gas pipeline, sewage system, etc.) are of great concern and may inhibit the fast and effective implementation of transit systems such as LRT and BRT. This is particularly true in areas where road infrastructure and street grids developed more than a century ago due to the potential for encountering unknown objects and systems that may require substantial time to remove.

\subsection{Why Consider BRT?}

According to TCRP Report 118, communities consider BRT a preferable mode of transportation for the following reasons (Kittelson \& Associates, 2007):

- BRT can be implemented either incrementally in phases or all at once because it uses an existing right-of-way (ROW). Phase-by-phase implementation allows time to assess public response and make appropriate adjustments. 
One of the advantages of completing the system all at once is the elimination of the need to repeat construction protocols, such as obtaining permits, performing environmental impact studies (EIS), etc.

- BRT is a flexible and cost-effective (from \$10 to \$27 million per lane-mile vs. LRT at close to $\$ 50$ million per lane-mile) rapid-transit system that can serve a variety of urban and suburban constituents.

- BRT can provide express and local services on a single system.

- BRT has the necessary attributes (easy boarding, speed, attractive and environmentally friendly vehicles, and distinctive system identity) to attract patrons from other modes. Also, off-vehicle fare collection and multi-door access tend to expedite passenger boarding.

- BRT can be effectively integrated into the surrounding environment and has proven to generate significant urban development benefits based on the experience of the Ottawa Transitway system, the Pittsburgh East and West Busway, the Boston Silver Line, and others.

\subsection{BRT Facilities in the USA}

Bus Rapid Transit can be classified as Light BRT and Heavy BRT. Light BRT shares road infrastructure with other traffic. Heavy BRT uses dedicated lanes and costs approximately $\$ 10$ - 27 million per lane-mile in comparison to $\$ 1-3$ million for Light BRT (Kittelson \& Associates, 2007).

There are more than 20 BRT systems spread all over the USA and more are in the planning stage (Gonsalves, 2012). Most BRT systems in the USA incorporate an increased level of station amenities and other unique features to distinguish themselves from standard bus service in addition to an enhanced quality of riding experience. An overview of 15 existing BRT systems' physical features indicated (GAO, 2012):

- 80 percent have station amenities.

- One third of them use dedicated lanes.

- 100 percent use some form of branding approach.

- 60 percent of them use some Intelligent Transportation System (ITS) features such as signal progression.

\subsection{Southeast Michigan and Its Future Mode of Transportation}

The Southeast Michigan region considered for this study consists of four counties: Macomb, Oakland, Washtenaw, and Wayne, which includes the City of Detroit (core city of the region). These four counties comprise the region covered by the Regional Transit Authority of Southeast Michigan (RTA). As the metropolitan planning organization (MPO) designated for the southeast Michigan region, the Southeast Michigan Council of Governments (SEMCOG), along with local government elected officials, has selected BRT as the mode of choice for future public transportation https://web.archive.org/web/20161031140647/http:/woodwardanalysis.com/eval uation/. Given the selection of BRT as the preferred future mode of public 
transportation in Southeast Michigan, a study was conducted to explore its probable economic impacts by examining attributes of various existing BRT systems. This paper documents the findings of this effort.

\subsection{Regional Transit Authority and BRT in Southeast Michigan}

A Regional Transit Authority (RTA) was established in 2013 for Southeast Michigan to address the mobility needs of residents. The RTA is composed of the counties of Wayne, Oakland, Macomb and Washtenaw including the city of Detroit. It is governed by a 10-member board with two from each county, one representative from the city of Detroit and one-non-voting member appointed by the governor who acts as the chair. The RTA will manage the planned BRT system. RTA just hired their first Chief-Executive-Officer (CEO). The planned BRT routes (very preliminary) known as the BRT triangle, cover only three counties (Figure 1). Total average daily ridership of the SEMCOG region as of

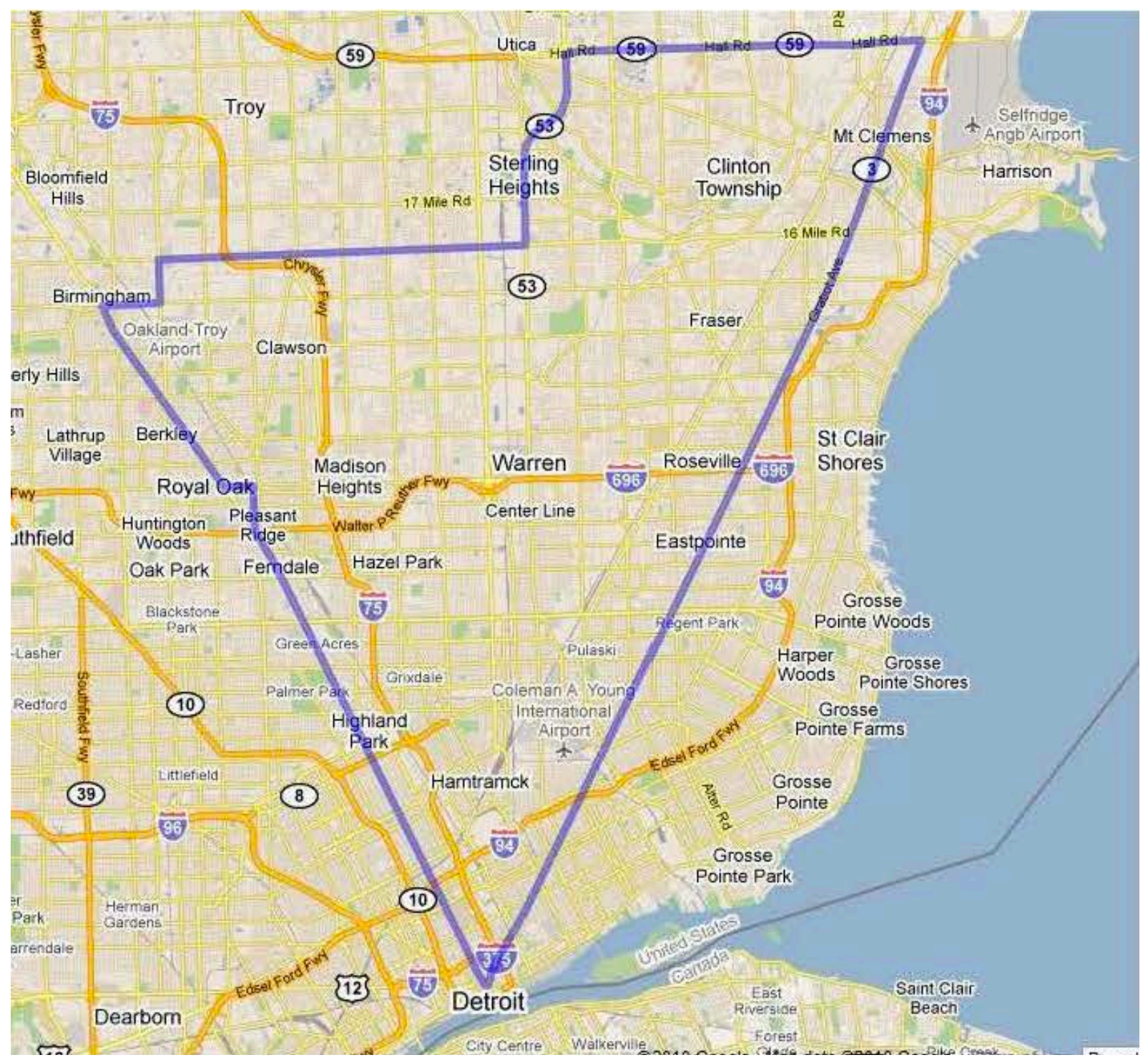

Figure 1. Planned tri-county BRT triangle Route (Anderson, 2011). 
2008 was around 188,204 , It is estimated that if BRT is introduced, average daily ridership will be 222,500 by 2030 (Detroit Transit Options for Growth Study, 2007). First phase of BRT route will be along the Woodward avenue from downtown Detroit To Birmingham. It is estimated that BRT daily ridership will be around 35,000 along the Woodward Avenue corridor from downtown Detroit to Birmingham

(http://www.candgnews.com/news/bus-rapid-transit-could-run-near-or-woodw ard-median, 2014). It is to be noted that existing daily bus ridership along this route is around 13,000

(http://www.smartgrowthamerica.org/documents/detroit-working-paper-1_4-20 13.pdf, 2014).

\section{Existing Transit in Southeast Michigan Counties}

There are seven transit service providers in the four counties of Southeast Michigan. However, the City of Detroit and three counties, namely Wayne, Oakland and Macomb are serviced by the Detroit Department of Transportation (DDOT) and Suburban Mobility Authority for Regional Transportation (SMART).

DDOT is the largest of these providers with a daily ridership of 124,514 . SMART carries about 34,000 riders per day. Detroit People Mover carries 4000 patrons per day

(http://www.smartgrowthamerica.org/documents/detroit-working-paper-1_4-20 13.pdf, 2014).

\section{Community and Investment Related Impact of BRT/Transit: Experience of Various Cities}

BRT has been in existence in North America for more than thirty years. Data on the potential impact of BRT on ridership, development along corridors, job sectors, land values, and other elements are fragmented. As part of this study, the authors attempted to identify the influence of BRT in terms of employment sectors, ridership, system-related investment, property values, and job creation by examining the experiences of cities where BRT is in use. This review explores economic impacts by highlighting them from two different but closely connected categories: 1 ) impacts of BRT presence on the community and 2) investment-related impacts of BRT implementation.

\section{Impacts of BRT Presence on the Community}

Nelson et al. (2012) conducted a study to determine BRT-advantaged job sectors by performing a shift-share analysis along the Eugene-Springfield BRT system (Nelson et al., 2012). A group or sector is said to be "BRT-advantaged" when its population grows at a higher rate within a BRT shed than within the larger metropolitan region during the same time period. Employment sector data reported at the two digit-level of the North American Industrial Classification System (NAICS) for two periods 2004 and 2010 were used in this context. Nelson et al. concluded that a number of job sectors namely Retail Trade, Transportation and 
Warehousing, Finance and Insurance, Real Estate and Rental Leasing, Education, Administrative service, Information, and other services appear to be attracted to BRT station area or transit zone. However, it was stated that cause and effect relationship between BRT location and increasing concentration of certain type of jobs within the proximity of BRT is not conclusive. At the same time these findings are consistent with findings of Belzar, et al. for transit (Belzar et al., 2011).

In order to examine the character of employment clusters that are located near transit, the Center for Transit Oriented Development (CTOD)examined 34 metropolitan areas (regions) in the U.S. with commuter rail, light rail, trolley, streetcar and bus rapid transit (BRT) corridors with designated lanes (Belzar et al., 2011). As a part of this study data were collected using CTOD database of transit areas in all 34 transit regions in the United States. In this study Transit Region and Transit Zone are defined as follows:

- Transit Zone: the area defined by a circle with a half-a-mile radius surrounding a transit station.

- Transit Region: a metropolitan region, geographically defined by the Center for Neighborhood Technology and by at least one transit corridor.

The key findings of the CTOD study are:

- Approximately one-fourth of all jobs in the transit regions studied are located near transit station. In 2008, 23 percent of all employment (14 million) in the transit region was located within half a mile of existing transit stop.

- The greater the number of stations in a region's transportation system, the greater the share of its jobs was accessible by transit.

- Station areas exhibited one percent increase in absolute employment.

- Sectors that exhibited especially strong growth within half-a-mile of station area during 2002-2008 were Arts, Entertainment, Recreation, Food Service and Accommodation (each growing by 14 percent), Health Care (10 percent) and Social Assistance ( 9 percent). At the same time a 22 percent drop in manufacturing jobs within these transit zones was observed.

- In 2008, 42 percent of all public sector jobs were located in transit zones.

- About 36 percent of jobs in Professional, Scientific, and Technical services are located within half a mile of a transit station.

The Government Accountability Office (GAO) also attempted to quantify the economic development impact of BRT in several cities (GAO, 2012). A summary of economic development near BRT stations is presented below:

- Cleveland RTA (Health Line) has attracted more than \$4 billion worth of investment. It is to be noted that Cleveland BRT is a heavy BRT system (dedicated lane). The planned BRT route (preliminary) of the Southeast Michigan will pass through a number of medical facilities namely Detroit Medical Center, Henry Ford Health system and Beaumont Health system whose annual revenue is more than 11 billion dollars, lot more than Cleveland clinic. Emx of Eugene, Oregon another heavy BRT system also experienced morethan 100 million dollars investment.

- Even Kansas BRT (Light BRT) was able to receive \$25 million federal grant 
for urban reinvestment.

- Metro Rapid of Los Angeles, CA as well as Rapid Ride A line of Seattle, WA experienced limited success.

- It appears that heavy BRT has lot more investment potential than light BRT The GAO also identified a set of factors conducive to economic development near transit. They are:

- Physical BRT features that convey a sense of permanence to developers and businesses.

- Major institutional, employment and activity centers (such as the Cleveland Clinic) along or near the BRT corridor that can sponsor development projects.

- Transit supportive local policies and development incentives.

Breakthrough Technology Institute studied a number of BRT systems in North America and Australia to examine their development potential (Breakthrough Technologies Institute, 2008). As a part of this study authors interviewed numerous builders as well as government officials in each of the case study cities (Cleveland, Ohio; Boston, Massachusetts; Ottawa, Ontario and Brisbane, Australia). Their findings are summarized below:

- Both Cleveland and Boston were very successful in revitalizing their blighted corridors. In the case of Ottawa, the BRT was the focal point of a long term growth management policy.

- The York Region (Ontario) is building a BRT network that is being used as part of an intensification strategy.

- Boston's Silver Line waterfront demonstrated that BRT can provide the high capacity rapid transit needed to encourage high-density development in desired urban market.

The GAO (2012) also reviewed BRT ridership data of a number of systems and found that ridership increased significantly one year after implementation when compared to the ridership data of the previous transit service (GAO, 2012).

The GAO observed that:

- Ridership data of 13 BRT systems were compared with the previous transit service (typically Standard Bus service); twelve of them reported an increase in ridership of more than 10 percent during the first year of operation.

- Three BRT systems reported that increase in ridership continued for additional years. For example, RTC Rapid in Nevada experienced a 5 percent increase in ridership per year for the first three years of service.

- A reduction in travel time was cited as the prime factor influencing ridership increase. Headways of 10 minutes or less during peak hours also played an important role. Shorter headways also make it possible for student riders to live further from campus where rents are less expensive. According to FTA guidance, shorter headways are important factor in patrons' perception of service quality.

- A portion of the gains in ridership was attributed to an increase in choice 
riders.

- The wide range of increases in ridership among various cities was attributed to dramatic improvement in quality of service as well as to expansion of service compared to previous transit service. For example, Cleveland BRT replaced the busiest bus route within the city and surpassed its five-year projection in its second year of service

Victoria Park et al. conducted a before-after sales transactions analysis along the Boston Silver Line's Washington corridor (Park et al., 2012). Data on sales transactions of condominium units within one-quarter mile of the corridor were collected for the years 2000 to 2009. Since Silver Line's Washington street route was opened in 2002, this available data provided a comprehensive look at before and after sales trends. They observed that:

- In 2000, nearly two years prior to the opening of Silver Line, the average sale price per square foot of a condominium within one-quarter mile of the corridor was $\$ 344.59$ per square foot, price was $\$ 590.55$ in 2005 and then settled at $\$ 522.83$ in 2009.

- The Case-Shiller Condo Price indices for the greater Boston area were $\$ 100.26, \$ 173.74$ and $\$ 154.40$ in 2000, 2005, 2009 respectively

- Condo sales price per square foot along the BRT corridor increased slightly less proportionately than the overall index for the Boston region between 2000-2005.

- Between 2000 and 2009, before and after the implementation of BRT service, sale prices of surrounding condominium units increased by 52 percent per square foot, while Boston area condo price index increased 54 percent.

- Condos along the Washington BRT corridor fared similarly to other condos in the greater Boston area between 2000-2009.

Perk et al. (2009) also studied Pittsburgh's Martin Luther King BRT corridor to determine the effects of BRT station proximity on property values (Park et al., 2009). Using regression analysis, they identified a model relating property value and distance with $\mathrm{R}^{2}=0.8$ and a F-value of 845.55 . They found that the relationship between the distance to a BRT station and property value is inverse, decreasing as the distance from a station increases, but linear. Decreasing marginal effects were expressed as Equation (1).

Change in $\operatorname{Cost}(+/-)=20.737-0.018 *($ distance from the BRT station $)$

Deng et al. in their paper citied 12 BRT cities where positive land development impacts were noted between 1995 and 2009 (Deng et al., 2011). Cities investigated as a part of this study are Curitiba, Bogota, Boston, Los Angeles, Las Vegas, Orlando, Pittsburg, Ottawa, Adelaide, Brisbane, Kent and Seoul. In case of Bogota, after only two years of BRT operation residential rental costs increased between $6.8 \%$ to $9.3 \%$ for every 5 minutes walking time to BRT.

\section{Investment Related Benefits of BRT/Transit}

There are two types of investment in transit: 
- Capital investment supports purchases of equipment and facilities, including but not limited to rolling stock, track, guideways, and construction of terminals, maintenance facilities, stations, and parking lots. New Starts funding grants from the Federal Transit Administration (FTA) are an example of capital investment. The Regional Transportation Authority (RTA) of Southeast Michigan is planning to apply for FTA New Starts funds during the 2016-17 cycle.

- Operations includes support for associated jobs (drivers, maintenance workers, administrative, and other transportation agency workers), as well as procurement of supplies (fuel, electric power, parts, and materials) needed for continuing operations. The RTA will seek a new transit tax (mileage in a form of property tax) from the residents of the Southeast Michigan region to assist in BRT operations investment in 2016. It is to be noted that between 2008 and 2014 the Detroit Institute of Arts (DIA), the Detroit Zoological Society, and SMART have been successful in getting voter approval for additional taxes despite the Detroit bankruptcy and a depressed economy.

These direct investments in public transportation projects (such as BRT in Southeast Michigan) and services can support short-term construction jobs and longer-term transit operation jobs (drivers, maintenance and security staff, and administrative staff), as well as purchases of products/services that lead to indirect impacts on other business activity and employment. The job sectors cited above are related to the implementation and operation of any transit system. For example, building a system requires construction, creating a need to hire construction workers. These workers pay city, state, and federal taxes. Any transit system, including BRT, requires drivers, maintenance personnel, security staff, ticket checkers, administrative professionals, and various other employees in order to operate. Thus, operational investment should create long-term jobs in the sectors mentioned above. Again, the growth in job sectors due to operational investment in transit is independent of local or regional context. According to the American Public Transport Association (APTA) transit expenditures have a positive impact on the region in which they operate and those areas in which companies that provide transit agencies with products and services are located (APTA, 2013).

The Michigan Department of Transportation (MDOT) uses the Regional Economic Models Inc. (REMI) (2015) TranSight Michigan models to forecast economic benefits of transportation investments. REMI TranSightis a modeling technique used by various state departments of transportation for evaluating the total economicimpact of transportation projects (www.rami.com, 2015).

The economic impacts of capital and operations spending on public transportation can be categorized into three ways:

- Direct impact: Engagement of workers and businesses in the manufacture of BRT vehicles and control equipment and construction of station facilities and guideways.

- Indirect impact: Impacts on businesses that supply goods and services to fa- 
cilitate direct spending, such as job creation for suppliers of steel, concrete, wood, and other materials needed for BRT projects.

- Induced impact: Re-spending (multiplier effect) of worker income on consumer goods and services.

According to APTA, every $\$ 1$ million of spending on public transportation could create anywhere from 30 - 60 jobs, of which $48 \%$ are direct impacts, $12 \%$ indirect, and 40\% induced (APTA, 2013).

According to Weisbrod et al. (2014), $\$ 1$ billion of capital and operational transit investment can create as many as 15,400 and 24,200 full-time jobs, respectively, in the year following the investment (Weisbrod et al., 2014). A breakdown of job share by investment types, such as capital and operations, is shown in Table 1. The job sectors represent only investment-related sectors and do not include all job sectors of any transit region. Construction jobs will receive the most benefit from capital investment, whereas government- and transit-related jobs will benefit from investment in operations. There is no guarantee that capital and operational investment in metro Detroit will follow the national trend, However, the impact should be similar for those job sectors that are most impacted, namely construction (growth of 30 percent of capital investment) and government and transit (growth of 46 percent of operational investment). For example, jobs created by capital investment will almost always be primarily in construction, whereas jobs created by operational investment, should consistently be government- or transit-related. Table 1 displays the likely distribution of potential jobs that will be generated due to investment in the transportation sector. Please note that use of these growth factors for sectors other than Construction and Government and Transit is not recommended. At the same time, it

Table 1. Share of job gains (in percent) by sector due to capital and operational investment in public transportation.

\begin{tabular}{cccc}
\hline Sector & NACIS Codes & Capital Investment & Operations \\
Construction & 23 & 30 & Investment $^{\mathrm{b}}$ \\
Manufacturing & $31-33$ & 16 & 4 \\
Retail Trade & $44-45$ & 7 & 7 \\
Professional Service & $54-55$ & 7 & 5 \\
Health and Social Service & 62 & 6 & 7 \\
Admin. Service & 56 & 5 & 4 \\
Hotel and Restaurant & 72 & 5 & 5 \\
Finance and Insurance & 52 & 4 & 3 \\
Transportation & $48-49$ & 3 & 0 \\
Real Estate & 53 & 3 & 0 \\
Arts and Entertainment & 71 & 1 & 0 \\
Government and Transit & 92 & 0 & 36 \\
Wholesale Trade & 42 & 3 & 36 \\
Other Services & 81 & 6 & 36 \\
\hline
\end{tabular}

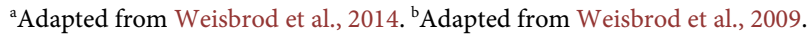


is impossible to positively predict the exact number of jobs that will be created by these investments without conducting an in-depth modeling.

According to American Recovery and Reinvestment Act (ARRA) of 2009, government spending of $\$ 92,000$ is needed to create one job year (one job for a duration of one year) (Executive Office of the President Council of Economic Advisers, 2009). The Grow America Act (GAA) of the Department of Transportation (USDOT) stated that every $\$ 1$ billion transportation investment creates 13,000 jobs https://www.transportation.gov/sites/dot.gov/files/docs/Workforce_DOT_Reuth =FINAL_2014.pdf.

\section{Potential Impacts of BRT in Southeast Michigan}

This section discusses the shift-share analysis used to identify BRT-advantaged age groups. The same approach was used by Nelson et al. to identify BRT-advantaged job sectors (Nelson et al., 2012).

BRT-advantaged age groups can be established by comparing related data before and after BRT implementation. Since post-implementation data are not yet available for Detroit, two BRT facilities in other cities (Cleveland's heavy BRT, HealthLine, and Kansas City's light BRT, Troost MAX) were adopted as surrogates for the purpose of this analysis. Of the two cities, Cleveland, with heavy BRT, is closer to Detroit in demographics, job sectors, and others.

Shift-share analysis is used to decompose increases or decreases in various attributes within a given area at two or more points in time (Nelson et al., 2012). The authors have identified components of the changes that are attributable to regional influence, growth within the attribute (such as age group), or local influence (such as BRTshed). The technique provides a picture of how a region's mix of industries and age groups is changing within a given timeframe. For the purpose of this analysis, age group data for the transit region, and transitshed for the years 2000 and 2010 were collected. This analysis decomposed age group data for the 2010 transitshed into three components:

- Regional share (RS)

- Age group mix (AM)

- Transit shed shift (TS)

\section{Regional Share (RS) Component}

RS is based on Equation (2) and answers the following questions:

- What percentage of the age group of class $(i)$ within a specific transit shed $(s)$ should change due to regional $(r)$ growth during analysis period?

- If the transit shed's age group grew at the same regional ( $r$ ) growth rate, what would be the result?

$$
R S_{i s}^{t}=E_{i s}^{t-n} \times\left(\frac{E_{r}^{t}}{E_{r}^{t-n}}\right)
$$

where:

$$
t=\text { end of analysis period (year); } t-n=\text { start of analysis period (year) }
$$


$i=$ specific age cohort group class; $s=$ specific transit shed

$E_{r}^{t}=$ Sum of all age groups at end of the analysis period $(t)$ for regional level (r)

$E_{r}^{t-n}=$ Sum of all age groups at the start of the analysis period $(t-n)$ for regional level $(r)$

$E_{i s}^{t-n}=$ Number of specific age group class (i) at start of the analysis period ( $t-$ n) for transit shed $(s)$

\section{Age Group Mix (AM) Component}

- Equation (3) defines the degree to which growth or decline of a specific age group class within a BRT shed is due to changes in those populations in the larger metropolitan region.

- AM estimates the share of growth of the transit shed $(s)$ age group class $(i)$ that is due to regional $(r)$ growth in age group class $(i)$.

$$
A M_{i s}^{t}=E_{i s}^{t-n} \times\left[\left(\frac{E_{i r}^{t}}{E_{i r}^{t-n}}\right)-\left(\frac{E_{r}^{t}}{E_{r}^{t-n}}\right)\right]
$$

where

$E_{i s}^{t-n}=$ Number of specific age group class $(i)$ at start of analysis Period $(t-$ n) forregion $(r)$

$E_{i r}^{t}=$ Number of Specific age group class (i) at the end of analysis period $(t)$ for region $(r)$

\section{Transit Shed Shift (TS) Component}

- TS is the growth in the age group class (i) in the transit shed due to attractiveness of the BRT. This residual volume is interpreted as uniqueness of BRT.

- TS Identifies the shed's leading and lagging age group class

$$
T S_{i s}^{t}=E_{i s}^{t-n} \times\left[\left(\frac{E_{i s}^{t}}{E_{i s}^{t-n}}\right)-\left(\frac{E_{i r}^{t}}{E_{i r}^{t-n}}\right)\right]
$$

where $E_{i s}^{t-n}=$ Number of specific age group class ( $\left.i\right)$ at start of analysis period $(t-n)$ for shed $(s) ; E_{i s}^{t}=$ Number of specific age group class $(i)$ at the end of analysis period $(t)$ for shed $(s)$.

\section{Application of Shift-Share Approach to Determine BRT-Advantaged Age Group}

To identify BRT-advantaged age group (s), the authors analyzed head-ofhousehold data for the Cleveland and Kansas City BRT sheds and metropolitan regions. Input Data and results of this analysis for Kansas Cityare presented in Table 2. In both cities, the 15 - 34 age group was identified as the BRT-advantaged group. For details readers may consult reference

(http://transweb.sjsu.edu/PDFs/research/1237-economic-impacts-of-bus-rapid-t ransit-in-southeast-michigan.pdf, 2016). Again, an advantaged or leading age group is one for which the group's growth rate within the BRT shed is higher 
Table 2. Shift-share analysis of household age group for Kansas city (Light BRT) 2000-2010.

\begin{tabular}{|c|c|c|c|c|c|c|c|c|c|c|}
\hline \multirow{2}{*}{$\begin{array}{l}\text { Age } \\
\text { Group }\end{array}$} & \multicolumn{3}{|c|}{ Region } & \multicolumn{3}{|c|}{ BRT Shed } & \multicolumn{4}{|c|}{ Reason for Change in Share by Age Group 2000-2010 } \\
\hline & 2000 & 2010 & Change & 2000 & 2010 & Change & $\begin{array}{l}\text { Region } \\
\text { Influence }\end{array}$ & $\begin{array}{l}\text { Age Group } \\
\text { Influence }\end{array}$ & $\begin{array}{c}\text { BRT } \\
\text { Influence }\end{array}$ & $\begin{array}{c}\text { \% Growth Due } \\
\text { to BRT }\end{array}$ \\
\hline $15-24$ & 38,380 & 35,928 & -2452 & 1344 & 1465 & 121 & $1500^{\mathrm{a}}$ & $-241.9^{\mathrm{b}}$ & $206.9^{c}$ & 14.1 \\
\hline $25-34$ & 130,110 & 135,977 & 5867 & 3060 & 3751 & 691 & 3415 & -217.3 & 553.0 & 14.7 \\
\hline $35-44$ & 165,222 & 146,198 & $-19,024$ & 2173 & 1836 & -306 & 2425 & -502.5 & -86.8 & -4.7 \\
\hline $44-54$ & 141,246 & 167,930 & 26,684 & 1976 & 1896 & -80 & 2205 & 143.9 & -453.3 & -23.9 \\
\hline $55-64$ & 89,164 & 136,775 & 47,611 & 1097 & 1826 & 729 & 1224 & 458.4 & 143.2 & 7.8 \\
\hline $65-74$ & 67,855 & 79,455 & 11,600 & 842 & 890 & 48 & 939 & 46.3 & -96.1 & -10.8 \\
\hline $74-84$ & 47,736 & 51,226 & 3490 & 728 & 542 & -186 & 812 & -31.3 & -239.2 & -44.1 \\
\hline $85+$ & 14,766 & 21,604 & 6838 & 331 & 232 & -99 & 369 & 114.8 & -252.3 & -0 \\
\hline Total & 694,468 & 775,093 & 80,625 & 11,551 & 12,438 & 887 & 12,892 & -229.4 & -224.6 & -1.8 \\
\hline
\end{tabular}

Source: Compiled from http://toddata.cnt.org/index.php (2014) (27). Notes: ${ }^{a}=($ Number in age group class (shed) in year 2000) $*($ Total region age group in $2010 /$ Total Region age group in 2000) $=1344^{*}(775,093 / 694,468)=1500$ (Equation \#2) ${ }^{b}=($ Number in age group class (shed) in year 2000)*(Number in age group class (region) in 2010/Number in age group class (region) in 2000)-a $=1344 *(35,928 / 38,380)-1500=-241.9\left(\right.$ Equation \#3) ${ }^{c}=($ Number in age group class (shed) in year 2000)*(Number in age group class (shed) in 2010/Number in age group class (shed) in 2000) $-\mathrm{a}-\mathrm{b}=1344 *(1465 / 1344)-1500-$ $(-241.9)=206.9$ (Equation $(4))$.

than its regional growth rate. Similarly, a lagging age group is one for which the group's growth rate within the BRT shed is less than its growth rate at the regional level. An assumption that was made for the purpose of this analysis is that if BRT has no effect on a region's age group composition, it would be the same after implementation of BRT as it was before implementation. There may be factors other than introduction of BRT that are more difficult to quantify. It should be noted that in the case of Cleveland, Kansas City, and other BRT cities, BRT was accompanied by changes in land policies that encouraged the $18-24$ and 25 - 34 age groups to live close to BRT. However, this action resulted in displacement of other age groups away from the BRT shed due to higher rent, noise, etc. The BRT Influence column in Table 2 shows that the growth of various age groups in the BRT shed was due to the introduction of the BRT. Moreover, according to the AAA, from 2007 to 2011 the number of cars purchased by the 18 - 24 and 25 - 34 age groups fell by almost 34 percent

(http://www.fastcoexist.com/3027876/millennials-dont-care-about, 2014). Only 44 percent of teens obtained a driver license within the first year of their eligibility, and only 54 percent were licensed before the age of 18 . A study by the University of Michigan's Transportation Research Institute (UMTRI) found that, in 2011, the 55 - 65 age group was 15 times more likely to purchase new vehicles than were young millennials (ages 18 - 24); moreover, consumers 75 years and up have been buying cars at higher rates than those in the 18 - 24 and 25 - 34 age groups https://web.archive.org/web/20130812112015/http://business.time.com:80/2013/ 08/09/the-great-debate-do-millennials-really-want-cars-or-not/. Although 18 24-year-olds rank lower in car ownership, they nonetheless travel for work, school, and recreation. From the experience of Cleveland and Kansas City, it can be stated that public transit is playing a role in this context. According to SEMCOG based on 2010 Census data indicated that more than 1.2 million (about 
25 percent) of residents in Southeast Michigan are 18 - 34 years of age http://semcog.org/Portals/0/Documents/Plans-For-The-Region/Transportation/Cong estion/CongestionManagementProcessPlanForSoutheastMichiganNovember2011.pdf. Transit planners should accommodate this trend when planning public transit systems.

\section{Potential Impact of BRT on Southeast Michigan Region and Suggested Courses of Action}

The authors attempted to identify the probable impact of BRT on the Southeast Michigan region based on the experience of other cities, APTA studies, and their own analysis.

\section{Job Sectors}

Job sectors that will be most impacted by BRT and BRT-related capital and operational investment are shown in Table 3. Also employment status of Southeast Michigan by job sectors as of 2012 is included in Table 3. At the time of this study, the amount and timeline of investment (capital or operational) had not been defined, thus the project team made qualitative estimates, such as types of jobs likely to be created due to BRT-related capital and operational investments. However, as soon as investment amounts are identified, a preliminary estimate on job sector impacts can be quantified using the tools included in this paper. For example, one probable BRT route under consideration is from downtown Detroit to Birmingham along Woodward Avenue. The length is about 20 miles. At a cost of $\$ 15$ million per mile, there is a possibility of more than $\$ 300$ million in capital investment in 2016. To estimate the job creation potential of a $\$ 300$

Table 3. Potential impact of BRT on job sector growth in southeast Michigan.

\begin{tabular}{|c|c|c|c|c|c|c|}
\hline \multirow[b]{2}{*}{ Job Sectors } & \multirow{2}{*}{$\begin{array}{l}\text { NACIS } \\
\text { Codes }\end{array}$} & \multirow{2}{*}{$\begin{array}{l}\text { Employment } \\
\text { in } 2012\end{array}$} & \multirow{2}{*}{$\begin{array}{c}\text { Percent of } \\
\text { Total } \\
\text { Employment }\end{array}$} & \multicolumn{3}{|c|}{ Source of Job Sector Share Influence } \\
\hline & & & & BRT-Advantaged & $\begin{array}{c}\text { Capital } \\
\text { Investment }\end{array}$ & $\begin{array}{l}\text { Operational } \\
\text { Investment }\end{array}$ \\
\hline $\begin{array}{l}\text { Natural Resources, Mining } \\
\text { and Construction }\end{array}$ & $11,21-23$ & 51,200 & 2.5 & & $\mathrm{X}$ (short-term) & \\
\hline Manufacturing & $31-33$ & 231,600 & 11.5 & & $\mathrm{X}$ & $\mathrm{X}$ \\
\hline $\begin{array}{c}\text { Trade, Transportation and } \\
\text { Utilities }\end{array}$ & $\begin{array}{l}22,44-45 \\
\quad 48-49\end{array}$ & 361,400 & 17.9 & $\begin{array}{c}\text { Trade and } \\
\text { Transportation only }\end{array}$ & $\mathrm{X}$ & $\mathrm{X}$ \\
\hline Information & 51 & 29,700 & 1.5 & $\mathrm{X}$ & $\mathrm{X}$ & $\mathrm{X}$ \\
\hline Financial Activities & 52 & 105,900 & 5.2 & $\mathrm{X}$ & $\mathrm{X}$ & $\mathrm{X}$ \\
\hline $\begin{array}{l}\text { Professional and Business } \\
\text { Services }\end{array}$ & $54-55$ & 361,300 & 17.9 & & $\mathrm{X}$ & $\mathrm{X}$ \\
\hline $\begin{array}{l}\text { Educational and Health } \\
\text { Service }\end{array}$ & $61-62$ & 324,500 & 16.1 & Only education & Only health & Only health \\
\hline Leisure and Hospitality & $71-72$ & 182,800 & 9.1 & $\mathrm{x}$ & $\mathrm{X}$ & $\mathrm{X}$ \\
\hline $\begin{array}{c}\text { Other Service } \\
\text { (Except Government) }\end{array}$ & 81 & 88,800 & 4.4 & $\mathrm{X}$ & $\mathrm{X}$ & $\mathrm{X}$ \\
\hline Government & 92 & 280,000 & 13.9 & & & $\mathrm{X}$ \\
\hline Total & & $2,017,200$ & 100 & & & \\
\hline
\end{tabular}


million capital investment, the project team sought the assistance of MDOT. MDOT Statewide and Urban Travel Analysis staff ran a scenario on the spending-only impacts of $\$ 300$ million in capital investment using a REMI TranSight model (TranSight Michigan 84-Area v3.2.5 ) with respect to the Detroit metro region. Weisbord's estimate as well as AARA and GAA formulas are also applied to predict the job creation potential of a $\$ 300$ million capital investment. The results of these analyses are presented in Table 4 . It is to be noted that Weisbord's estimate represents national job growth due to a $\$ 300$ million transportation investment in the Detroit region. However, construction-related job growth should be local. The total job creation potential estimated using various techniques ranges from 3200 to 4600 . Although the total number of potential jobs produced by the REMI model is 1200 fewer than the Weisbord estimate, the REMI Model estimates a greater number of construction-related jobs (1920) compared to Weisbord's estimate (1386). According to Glen Weisbord, ${ }^{1}$ regional job growth should account for approximately two-thirds of total national job growth. REMI's prediction of regional job growth is very close to two-thirds of Weisbord's national estimate. It is to be noted that total job growth predicted by the REMI model with respect to the Detroit metro region is close ( \pm 10 percent) to the total job growth computed by the ARRA and GAA formulas, which do refer to regional growth but not specifically to Detroit region.

Also BRT will contribute to the region's GDP. As cited previously, an increase in ridership of close to 20percent can be expected across the region due to BRT

Table 4. Estimates of job growth potential for a $\$ 300$ million capital investment using various approaches.

\begin{tabular}{|c|c|c|c|c|}
\hline Approach & $\begin{array}{c}\text { Total } \\
\text { Number } \\
\text { of Jobs }\end{array}$ & $\begin{array}{c}\text { Total Job } \\
\text { Creation } \\
\text { Factor }\end{array}$ & $\begin{array}{l}\text { Construction-Related } \\
\text { Jobs }\end{array}$ & $\begin{array}{l}\text { Construction-Related } \\
\text { Job Creation Factor }\end{array}$ \\
\hline $\begin{array}{l}\text { Weisbord's } \\
\text { estimate }\end{array}$ & 4620 & $\begin{array}{l}15.4 \text { jobs per } \\
\text { million dollar } \\
\text { investment }\end{array}$ & 1386 & $31 \%$ of total job \\
\hline $\begin{array}{l}\text { ARRA } 2009 \\
\text { Formula }\end{array}$ & 3240 & $\begin{array}{l}10.8 \text { jobs per } \\
\text { million dollar } \\
\text { investment }\end{array}$ & & Not available \\
\hline $\begin{array}{c}\text { Grow American } \\
\text { Act Formula } \\
\text { (GAA) }\end{array}$ & 3900 & $\begin{array}{l}13 \text { jobs per } \\
\text { million } \\
\text { dollars } \\
\text { investment }\end{array}$ & & Not available \\
\hline $\begin{array}{l}\text { REMI TranSight } \\
\text { Model } \\
\text { Considering } \\
\text { Detroit Metro } \\
\text { Region }^{\star \star}\end{array}$ & 3480 & $\begin{array}{l}11.6 \text { jobs per } \\
\text { million } \\
\text { dollars } \\
\text { investment }\end{array}$ & 1962 & $\begin{array}{c}6.54 \text { jobs per million } \\
\text { dollars investment }\end{array}$ \\
\hline
\end{tabular}

**Includes direct, indirect and induced statewide and urban travel analysis section, bureau of transportation planning, Michigan department of transportation. contact Susan Gorski, Manager.

${ }^{1}$ Author's one-on-one telephone conversation, with Glen Weisbrod (April, 2015). 
(from 188,204 in 2012 to 222,500 in 2030) and this should upwardly influence the SEMCOG region's GDP.

It is to be noted that BRT can be successful, and these impacts realized, only if the system is properly planned, designed and implemented, taking into consideration local attributes. Well-planned BRT is a potential catalyst for the stimulation of the identified advantaged job sectors. Knowing which job sectors have a track record of thriving in a BRT shed will help communities and their planners target the appropriate job sectors in their marketing efforts.

\section{Travel Time and Emissions}

The latest data available on the Southeast Michigan region indicated that close to 90 percent of arterial miles were at low-to-moderate congestion levels (Figure 2). Therefore, a reduction in auto travel due to the introduction of BRT will yield neither a significant savings in travel time nor a significant reduction in emissions and noise. These are therefore not considered benefits of BRT in this region. However, while time spent on actual travel may not be reduced, BRT will eliminate the time required to find parking and walk to one's final destination from the parking location. Moreover, BRT will reduce the cost of travel for riders by eliminating, at minimum, the cost of parking. Parking in downtown Detroit facilities costs from $\$ 7$ - \$15 per day, which is at least twice the standard transit fare.

\section{Transit Ridership Base}

The shift-share analysis conducted using data from Cleveland and Kansas City identified 15 - 34 as the BRT-advantaged age group. According to SEMCOG, in 2010 more than 1.2 million people within this age group lived in Southeast Michigan. Based on the experiences of Cleveland and Kansas City, when BRT is implemented in Southeast Michigan many of these residents should be motivated to live within the shed, broadening the transit ridership base which, in turn, has the potential to increase BRT ridership. Moreover, many workplaces

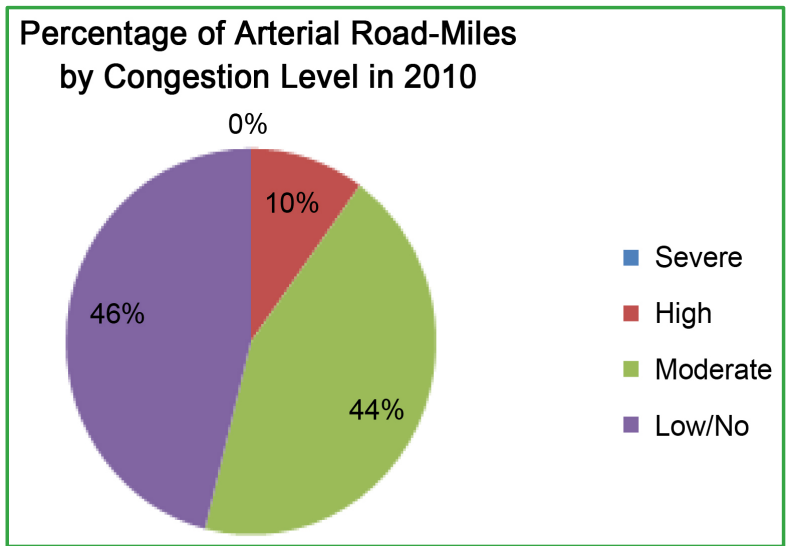

Figure 2. Congestion level of arterials road-miles in SE Michigan

http://www.semcog.org/Plans-for-the-Region/Transportatio n/Regional-Transportation-Plan-RTP. 
and institutions of higher learning are located along the planned BRT routes, including the Detroit Institute of Art (DIA), the Detroit Zoo, Detroit Medical Center, Henry Ford Health System, Beaumont Health System (the largest employer in Oakland County), Wayne State University (with a student population of more than 35,000), Oakland Community College, and the Michigan Science Center. Choice riders visiting these facilities may find it more convenient to take BRT due to savings in parking costs.

\section{Land Development}

Most cities with BRT have seen a positive impact on land development after the implementation of BRT (Deng et al., 2011). Southeast Michigan's planned BRT route will traverse a number of blighted corridors. If the experience of other cities is replicated, these blighted corridors could see a rebirth of development in the near future.

Michigan RTA officials can perform a sensitivity analysis using Equation 1 to examine the impact of BRT routes on the land value as a part of strategic planning. (This approach is explained in the Impact of BRT presence on the community section). Like Cleveland's BRT, Detroit's system will pass a number medical facilities. In addition, it will pass Wayne State University, a pro baseball stadium, a pro football stadium, a pro hockey stadium, museums, and the Detroit Zoo. With such attractions within close proximity of the planned route, a quality, well-planned BRT should attract transit-oriented developments (TOD). However, policy makers, elected officials, the land bank authority, and real estate developers should plan to play an active role in this regard. To encourage TOD, the following actions should be considered:

Use public-private partnerships (PPP) to fund TOD and walkable streets (a transit mall would be a good example of PPP).

Work closely with the Michigan Land Bank, with the assistance of the Urban Land Institute. ${ }^{2}$

Encourage local government to contribute more than 32 percent (Detroit's current local contribution) of yearly operations costs.

Pursue HUD and USDOT grants that support transit-oriented development (TOD).

Provide GIS-based economic, demographic, land use, transit, and walkability data for potential TOD developers to encourage and facilitate their plans around BRT.

Work with cities along the main transit corridors to develop consistent corridor-wide zoning. The RTA could suggest best practices for TOD-favored zoning (or even a master plan).

Consider Smart Street concepts when building transit routes. According to Smart Growth America, "Complete Streets are streets for everyone. They are de-

${ }^{2}$ State of Michigan, Michigan Land Bank Fast Track Authority [website] (no date),

http://Michigan.gov/landbank (accessed August 3, 2013).

${ }^{3}$ Smart Growth America "National Complete Street Coalition"

www.smartgrowthamerica.org/complete-street/ (Accessed Feb. 10, 2014) 
signed and operated to enable safe access for all users, including pedestrians, bicyclists, motorists and transit riders of all ages and abilities. Complete Streets make it easy to cross the street, walk to shops, and bicycle to work."”

Work closely with existing agencies, such as the Woodward Avenue Action Association (WA3) and Golden Spike, to promote TOD concepts along the Woodward corridor and other transit corridors.

Promote the tax benefits of riding public transit (including BRT). Federal tax code allows employers to purchase BRT passes through employers with pre-tax dollars. ${ }^{4}$

\section{Ridership}

If BRT is implemented along the Woodward Avenue route, it is estimated that the route's average daily ridership will be around 35,000-close to three times the current ridership. As stated before, introduction of BRT in various cities has increased ridership on specific routes by anywhere from 2 percent to 80 percent within a year. Twelve out thirteen cities with BRT have experienced ridership increases of 10 percent or more; it is reasonable to expect Detroit to follow this trend. However, this increase will not materialize without participation by choice riders. In 2012, average daily vehicle miles traveled (VMT) on Southeast Michigan roadways was 118 million

http://www.semcog.org/Plans-for-the-Region/Transportation/Regional-Transpo rtation-Plan-RTP. As stated earlier, a planned, multiphase implementation of BRT has the potential to increase daily ridership by 34,000 . From the experience of other BRT cities, it can be stated that choice riders (those who will use BRT, instead of their cars) will play a role in this increase. Thus, there is a potential for a decrease in daily VMT, resulting in reduced traffic and emissions.

\section{Federal, State, and Local Treasury Impacts}

Investment in transit, both capital and operational, should generate additional tax revenue at federal, state and local levels in the form of corporate/dividend taxes, personal income taxes, and social security contributions. The benefits of BRT will be realized in the form of TOD, job growth, increases in land value and property taxes, and other long-term impacts, but care should be taken to educate stakeholders and the public that under no circumstances can BRT produce direct equivalent returns on capital investments..

\section{Median Income}

Between 2000 and 2009, six BRT regions experienced an increase in median income by more than 13 percent (Figure 3) compared to 8 percent for the Detroit transit region. If Southeast Michigan's experience follows suit, implementation of BRT should contribute to an increase in the rate of income growth.

${ }^{4}$ Sun Trans "Commute to work" http://www.suntran.com/commuter_tacben.php (Accessed Feb. 10, 2014). 


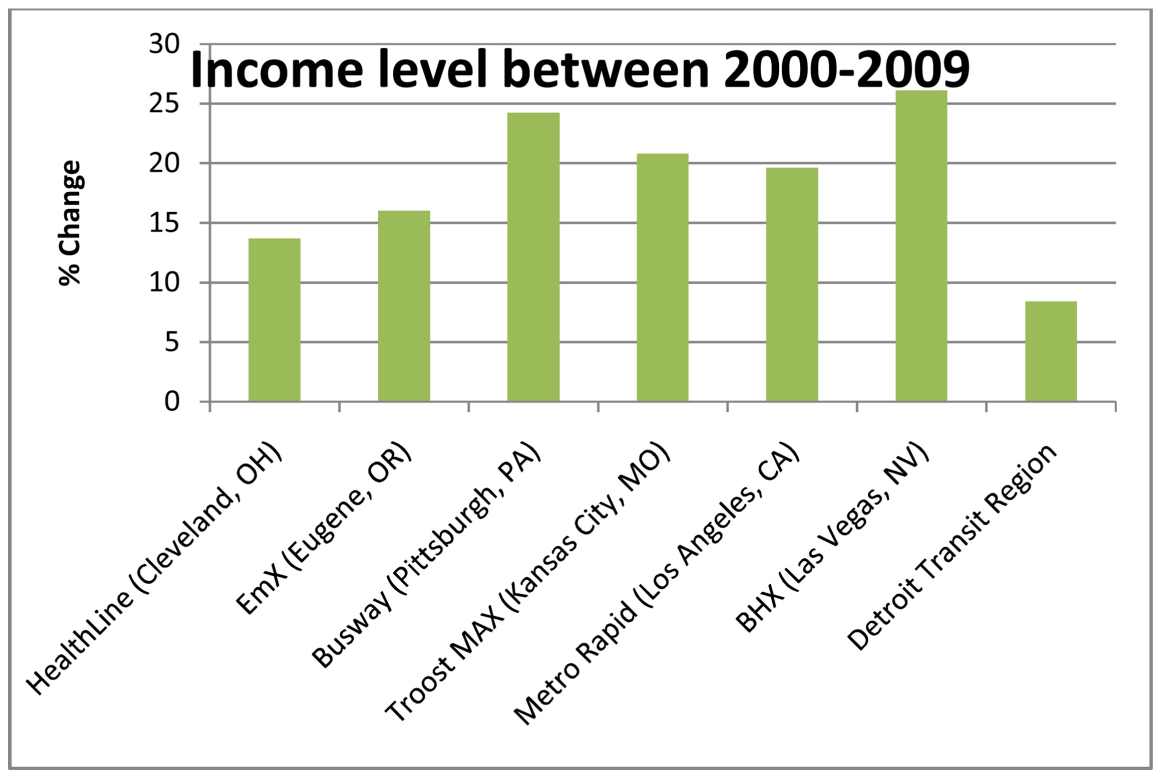

Figure 3. Changes in income level between 2000-2009 in various BRT. Cities and Metro Detroit

http://www.semcog.org/Plans-for-the-Region/Transportation/Regional-Transportatio n-Plan-RTP.

\section{Conclusions and Recommendation for Future Study}

In this paper, a framework has been developed to identify the probable economic impacts of BRT in Southeast Michigan. The authors investigated a number of cities that have implemented BRT, including Cleveland, Kansas City, and Pittsburgh, to identify BRT/transit-advantaged job sectors and age groups. The authors also examined specific attributes of Southeast Michigan, such as job sectors, population by age group, vehicle miles traveled, median income growth, and congestion level, and discussed BRT's potential influence on them. This study identifies the job sectors and age group most likely to be advantaged by BRT, based on the experiences of other cities and the specific attributes of Southeast Michigan.

The planned BRT system is currently in the very early stages of development. The RTA has not established any detailed plan regarding routes or other courses of action. BRT in Southeast Michigan has the potential to deliver economic benefits comparable to those of other cities if the design, planning, and implementation follow the suggested course of actions outlined in this report. The following list briefly summarizes the features necessary to derive maximum economic benefits from BRT:

- Dedicated lanes (heavy BRT)

- Upscale branding distinguishing the system from standard transit

- Improved levels of service

- Security system (video camera)

- All-season climate control

- Off-vehicle fare collection with modern payment options

- Responsiveness to the local population (e.g., disabled population). 
The formula for computation of land value impacts (Equation (1)) may be used to perform sensitivity analysis to determine future BRT routes. The implementation of BRT in Southeast Michigan is still a few years away, and it will have to overcome a number of political and funding hurdles. In addition, integration of all regional transit systems under the RTA will be a formidable task. However, public transit systems in Cleveland, Denver, and St. Louis have been coexisting and integrating without major issues.

Finally, to produce the maximum economic benefits, the planned BRT must be able to attract choice riders as well as enhance the experience of transit dependent riders.

Findings of this study are:

- Heavy BRT has a greater potential to produce economic benefits.

- Arterial corridors in Southeast Michigan are currently at low-to-moderate congestion levels; therefore BRT will not significantly improve travel times or reduce emissions and noise. However, other benefits-namely land development, job growth, improved ridership base, reduction in travel costs, and an improved tax base-can be expected.

- Tax incentives and the high cost of parking at work can attract choice riders. Federal law currently allows employers to offer employees the opportunity to purchase BRT passes with pre-tax dollars, providing a financial incentive for using transit. These benefits are available only through employers.

- Making development-related data readily available and fostering cooperation among agencies will encourage transit-oriented development.

- Capital investment will produce a significant number of short-term construction-related jobs. Due to the multiplier effect, these jobs will benefit the region economically in the near term.

- Operational investment will generate long-term government and transit-related jobs, specifically, drivers, maintenance personnel, and security and administrative staff.

- Roadway characteristics, job locations, demographics, and other unique local attributes should be taken into account at every stage of development rather than simply duplicating a successful system located elsewhere. For example, $19 \%$ of Detroit residents are physically disabled. Facts such as this should be considered when choosing system amenities, such as automatic level boarding.

- In a few years after the implementation of BRT, a shift-share analysis should be performed to determine the job sectors and age group advantaged by BRT implementation. Such an analysis will validate this study's models for use by other regions that may be considering BRT.

The planned BRT system has the potential to foster greater sustainability in the region, more efficient public transportation, and most importantly, a more reliable mode of transportation for those who must rely on transit and those who would choose to forego dependence on automobile travel if a viable alternative is offered. At the same time, there are challenges that must be overcome. It is 
the authors' hope that the current leadership has the will and desire to embrace strategies (some of them already envisioned by SEMCOG) that will make Southeast Michigan a more vibrant community in which to live, work, and raise a family.

\section{References}

Anderson, S. (2011). Rolling Rapid Transit. A Report by Anderson Consulting.

APTA (2013). 2013 Transit Fact Book

Belzar, D. et al. (2011). Transit and Regional Economic Development. Oakland, CA, CTOD.

Breakthrough Technologies Institute (2008). Bus Rapid Transit and Transit Oriented Development. Report, April 2008.

Deng, T. et al. (2011). Recent Development in Bus Rapid Transit: A Review of Literature. Transport Reviews, 13.

Detroit Transit Options for Growth Study (2007). Mode Choice Methodology Memorandum: A Correspondence from Tim Roseboom, Manager Strategic Planning Detroit Department of Transportation to Jennifer Evans. SEMCOG, 8 February 2007.

Executive Office of the President Council of Economic Advisers (2009). Estimates of Job Creation from the American Recovery and Reinvestment Act of 2009. May 2009.

General Accounting Office (GAO) (2012). Bus Rapid Transit Projects Improve Transit Service and Can Contribute to Economic Development. Report \# GAO-12-811, July 2012.

Gonsalves, J. (2012). What Is BRT. A Power Point Presentation by Parson Brinckerhoff Inc., 22 February 2012 at the National BRT Institute, University of South Florida.

Kittelson \& Associates (2007). Bus Rapid Transit Practitioner's Guide. TCRP Report \# 118, Washington DC.

Nelson, A. C. et al. (2012). Bus Rapid Transit and Economic Development Case Study of the Eugene-Springfield, Oregon BRT System. Paper presented at the Transportation Research Board Meeting, Washington DC, January 2012.

Park, V. et al. (2009). Land Use Impact of Bus Rapid Transit: Effects of BRT station Proximity on Property Values along the Pittsburgh Martin Luther King Jr. East Busway. FTA Report\#FTA-FL-26-7109.2009.6, December 2009.

Park, V. et al. (2012). Land Use Impact of Bus Rapid Transit: Phase II-Effects of BRT Station Proximity on Property Values along the Boston Silver Line Washington Corridor. FTA Report\# 0022, July 2012.

Regional Economic Models, Inc. (REMI) (Accessed 10 October 2015). http://www.remi.com/products/transight

Weisbrod, G. et al. (2009). Economic Impact of Public Transportation Investment. Report Prepared for American Public Transportation Association, October 2009.

Weisbrod, G., Cutler, D., \& Duncan, C. (2014). Economic Impact of Public Transportation Investment: 2014 Update. 
Submit or recommend next manuscript to SCIRP and we will provide best service for you:

Accepting pre-submission inquiries through Email, Facebook, LinkedIn, Twitter, etc. A wide selection of journals (inclusive of 9 subjects, more than 200 journals)

Providing 24-hour high-quality service

User-friendly online submission system

Fair and swift peer-review system

Efficient typesetting and proofreading procedure

Display of the result of downloads and visits, as well as the number of cited articles Maximum dissemination of your research work

Submit your manuscript at: http://papersubmission.scirp.org/

Or contact cus@scirp.org 